\title{
ТЕОРЕТИЧНІ ОСНОВИ ФОРМУВАННЯ КРИМННАЛІСТИЧНОЇ ХАРАКТЕРИСТИКИ РОЗБІЙНИХ НАПАДІВ НА ІНКАСАТОРІВ
}

\author{
ЯГОЛЬНИК Олег Михайлович - здобувач Донецького юридичного інституту \\ МВС України \\ УДК 343.98:343.712.1 \\ DOI:10.32782/NP.2020.2.18
}

\begin{tabular}{|c|}
\hline 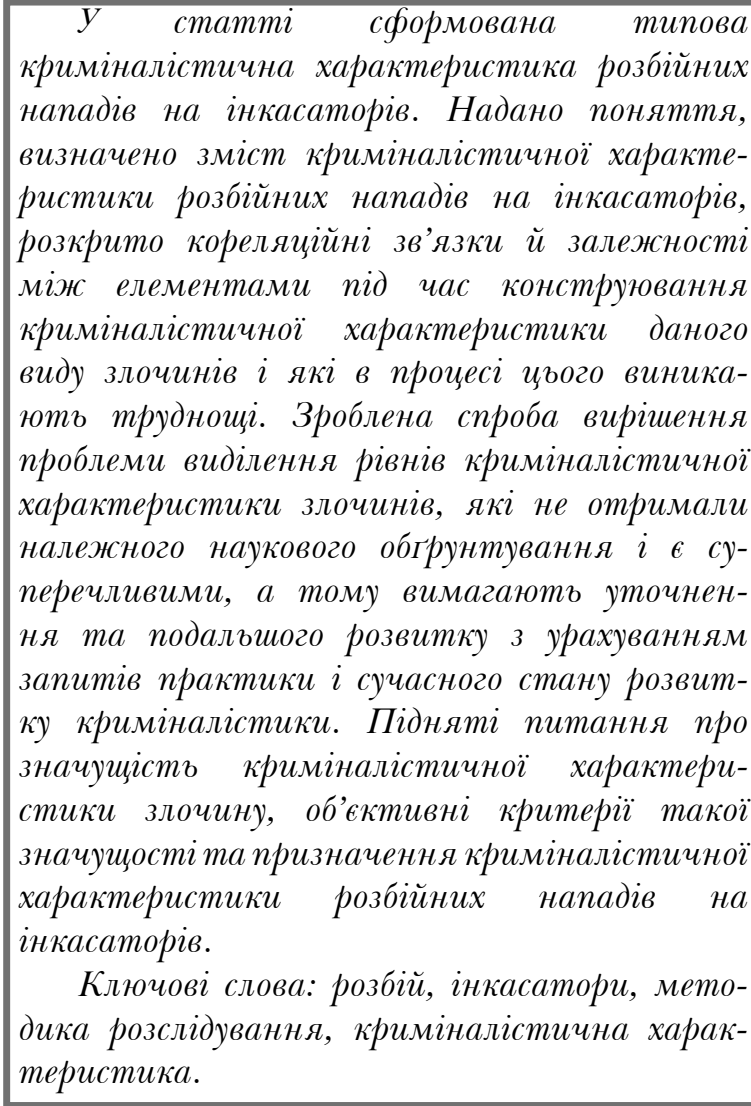 \\
\hline
\end{tabular}

Складною проблемою сьогодення є питання про розбійні напади на інкасаторів, характерними рисами яких є підвищена суспільна небезпека та резонанс, який виникає у зв'язку з відкритим, незаконним, насильницьким нападом на транспортні засоби, поєднаний із посяганням на здоров'я і життя людей, що носить, як правило, груповий організований характер із застосуванням вог- непальної зброї й спрямований на заволодіння матеріальними цінностями у великих розмірах. Під час таких нападів часто гинуть не тільки інкасатори, а й сторонні люди, у зв'язку з тим, що в основному такі напади відбуваються в денний час та в людних місцях, біля великих магазинів та банківських установ.

У той же час, в умовах перманентної соціальної та економічної кризи, зростання безробіття та падіння матеріального рівня громадян, неможливості задоволення значної частини населення основних потреб легальними способами, продовження конфлікту на Сході країни (нелегальне поширення зброї, боєприпасів та вибухівки, зростання соціально-побутової невлаштованості осіб, яких торкнулися наслідки збройного конфлікту та психологічного напруження), втрати соціального контролю та деяких прорахунків, що були допущені при реформуванні правоохоронної системи, розроблення ефективних заходів протидії розбійним нападам на інкасаторів має стати пріоритетним напрямом державної політики боротьби зі злочинністю, дієвим засобом захисту життя та здоров’ я людей і власності.

Необхідність підвищення якості роботи підрозділів поліції щодо розслідування розбійних нападів, вчинених на інкасаторів, ставить чіткі завдання перед криміналістичною наукою, серед яких удосконалення криміналістичної характеристики даного виду злочинів і розробка на їі основі системи необхідних практиці дієвих методичних 


\section{Кримінальне право, кримінальний процес та криміналістика}

рекомендацій, що розкривають особливості комплексу типових версій і планування в справі, організації розслідування та взаємодії слідчого з оперативними підрозділами й громадськістю, використання спеціальних знань, техніко-криміналістичних засобів i методів, специфіки проведення окремих слідчих (розшукових) дій з метою виявлення обставин, що сприяють вчиненню злочинів, і запобіганню новим розбійним нападам.

Для повного й об'єктивного розгляду проблем формування криміналістичної характеристики розбійних нападів на інкасаторів варто дослідити принципові питання криміналістичної характеристики злочинів, що визначають її сутність.

Вперше про криміналістичну характеристику злочинів і про їі елементи висловлювався у своїх роботах А. М. Колесниченко [1]. Його теоретичну ідею підтримало багато вчених, i тому питання про криміналістичну характеристику злочинів одержало свій подальший розвиток. Учені-криміналісти, що досліджують проблеми криміналістичної характеристики, не завжди однотипно підходять до визначення її поняття і системи.

Якзазначалося вище, науковціпо-різному розглядають поняття криміналістичної характеристики злочину. Так, А. Я. Драпкін розглядає її як «...наукову категорію, в якій 3 достатнім ступенем конкретності описані типові ознаки й властивості події, обстановки, способу та механізму вчинення суспільно небезпечних діянь певної класифікаційної групи, процесу виникнення та локалізації доказів, типових ознак особистості та поведінки винних, потерпілих, а також стійкі особливості інших об'єктів посягань» [2, с. 17].

Так, Р. С Бєлкін відзначає, що криміналістична характеристика окремого виду злочину повинна містити в собі характеристику типової вихідної інформації, систему даних про способи вчинення і приховання цього виду злочинів і типових наслідків їх застосування, характеристику особистості типового злочинця, типових мотивів і цілей злочину, особистості потерпілих, деяких обставин вчинення злочину (часу, місця, обстановки) [3, с. 16-17].

В. Г. Гончаренко розглядає зазначену категорію як ідеальну модель типових зв'язків і джерел доказової інформації, що закономірно формуються, яка дозволяе прогнозувати оптимальний шлях та найбільш ефективні засоби розслідування окремих категорій злочинів [4, с. 12]. Він же пропонує розглядати іï на філософському рівні, інтерпретувавши іiі як абстрактну інформаційну структуру розслідуваної події даного виду, закономірно і детерміновано відображеної в реальному світі. Як складові елементи криміналістичної характеристики злочинів автори пропонують такі елементи: тип (вид, рід, категорія) події; засіб вчинення і приховання злочину; типові джерела матеріально-фіксованої інформації; типові джерела вербальної інформації; коло осіб, де може знаходитися особа, що вчинила злочин; типові мотиви i цілі вчинення такого роду злочинів [4, с. 15].

Деякі автори наголошують, що криміналістична характеристика злочинів - це заснована на практиці правоохоронних органів i криміналістичних досліджень модель системи зведених відомостей про криміналістично значущі ознаки виду, групи або конкретного злочину, яка має на меті оптимізувати процес розкриття та розслідування злочину [5, с. 255]. А вже інші науковці формулюють іiі як інформаційну модель, що відображає узагальнені ознаки елементів злочину та їх закономірних (кореляційних) зв’язків [6, c. $6 ; 7$, с. 63$]$.

А. М. Колесниченко криміналістичну характеристику визначив як систему відомостей про криміналістично значимі ознаки злочинів даного виду, що відображає закономірні зв'язки між ними та служить побудові і перевірці слідчих версій для рішення основних задач розслідування [8, с. 56]. До істотних ознак їі змісту він відніс: 1) відомості про криміналістично значимі ознаки злочину даного виду; 2) систему відомостей, що включає дані про закономірні зв'язки між ознаками злочинів; 3) систему відомостей, які служать побудові і перевірці слідчих версій для рішення конкретних задач розслідування.

У свою чергу, М. В. Салтевський зазначив, що криміналістична характеристика для методики розслідування злочину має важливе завдання, оскільки вона слугує вірогідною моделлю конкретного злочину, 
віднесеного до певного виду. Криміналістична характеристика - це видова модель, яка дозволяє прогнозувати, будувати найбільш обгрунтовані версії щодо обставин конкретної події (особи, способу вчинення злочину, засобів злочину та іншого) [9, с. 148-151]. В. Д. Берназ визначає дану категорію наступним чином: «..це основана на державних статистичних даних науково обгрунтована система узагальненої інформації та їх джерел про обставини, які були доказані, та інші, які мали значення для попередження, виявлення, розкриття, розслідування та судового розгляду досліджуваних злочинів зазначеної категорії» [10, с. 17].

А. Ф. Волобуєв зі свого боку вважає, що криміналістична характеристика - це система відомостей (знань) про елементи механізму скоєння злочинів окремого виду або групи, в яких відображаються закономірні зв'язки між цими елементами і які використовуються для побудови і перевірки версій під час розслідування конкретних злочинів [11, с. 24]. А вже Н. П. Яблоков визначає криміналістичну характеристику злочину як систему опису криміналістично значимих ознак виду, групи й окремого злочину, які виявляються в особливостях способу, механізму й обстановки його вчинення, що дає уявлення про злочин, особистість його суб'єкта й інші обставини, про певну злочинну діяльність і яка призначена забезпечити успішне вирішення задач щодо розкриття, розслідування і попередження злочинів [12, c. 45$]$.

Доречно вказати, що М. Г. Щербаковський визначив криміналістичну характеристику одночасно з точки зору кримінально-правової і криміналістичної характеристики [13, с. 123]. В. I. Шиканов, зокрема, формулював, що «доцільно також відмовитися від площинного рішення моделі характеристики злочину, яке стало вже традиційним. Залежно від безпосередніх цілей, які стоять перед слідчим, слід визначити ядро міждисциплінарної моделі того чи іншого виду злочину (наприклад, час вчинення злочину, спосіб вчинення злочину, особа потерпілого тощо) і навколо нього конструювати об’ємну модель» [14, с. 40-43]. І. М. Кубрак, розмежовуючи поняття криміналістичної характеристики на загальну криміналістичну характеристику злочинів і конкретну характеристику, що стосується окремого виду або групи схожих за кримінально-правовими ознаками, розглянув конкретну криміналістичну характеристику як систему відомостей про сукупність криміналістично значимих ознак, згрупованих у залежності від типових особливостей виду, або груда злочинів і відображення сторін їхнього механізму в обумовлених життєвих ситуаціях і матеріальній обстановці, у яких вони відображаються [15, с. 16].

Цікавою 6 думка В. К. Весельського, який вважає, що криміналістична характеристика злочину належить до основних положень методики розслідування, а стосовно конкретних методик певною мірою є основою їх побудови. Ця характеристика визначає найважливіші положення методики розслідування злочинів. Перебуваючи у складі криміналістичної методики, вона покликана виконувати функцію побудови оптимальних методів розслідування. Також зазначає, що для розробки методики розслідування злочинів важливо виявити не тільки структурні елементи криміналістичної характеристики злочину, але і встановити наявні між ними закономірні зв'язки [16, с. 95].

Аналіз вище викладених визначень поняття криміналістичної характеристики злочину дає можливість виділити ряд ознак, властивих якщо не всім, то більшості з цих визначень. Думки більшості авторів схожі в тому, що криміналістична характеристика злочинів - це: 1) сукупність даних (відомостей), інформація про злочини, які характеризуються, і певні, пов'язані із ними явища; 2) сукупність (система) ознак властивостей, слідів, відношень злочину; 3) інформація, що має криміналістичне значення; 4) характеристика конкретного, реального злочину і наукова абстракція двох рівнів, яка виділяє типові ознаки певних категорій злочинів (видів і груп) і злочину взагалі; 5) важливий елемент окремої методики.

На нашу думку, найбільш точно та повно визначили досліджувану категорію О. Н. Колесниченко і В. О. Коновалова наступним чином: « Це система відомостей (інформації) про криміналістично значущі ознаки зло- 


\section{Кримінальне право, кримінальний процес та криміналістика}

чинів даного виду, що відбиває закономірні зв’язки між ними і служить побудові та перевірці слідчих версій для вирішення конкретних завдань досудового розслідування» $[8$, c. 16$]$.

Отже, дані, що обособлюють сутність криміналістичної характеристики розбійних нападів на інкасаторів, становлять собою структуровані криміналістичні відомості, що характеризують досліджуване кримінальне правопорушення. На наш погляд, криміналістична характеристика таких кримінальних правопорушень - це інформаційна система, яка включає сукупність даних про криміналістично значущих ознак та властивостей вчинення розбійних нападів відповідно до певного часу і регіону, відображає закономірні їх зв’язки й використовується при побудові типових версій, прийнятих за основу в процесі розслідування.

Отже, основною проблемою недостатньої практико-прикладної цінності криміналістичної характеристики злочинів як узагальнювальні категорії $\epsilon$ упущення в структуруванні криміналістично значущої інформації в межах розглядуваного поняття, тому що виділення надмірної кількості елементів призводить до неможливості їх сукупного використання в діяльності слідчого. Вчені виділяють два основні положення, дотримання яких сприятиме вдосконаленню структуризації криміналістично значущої інформації про подію злочину: 1) вихідні елементи не повинні визначатись один через інший, знаходячись на одному рівні абстрагування [17, с. 55]; 2) вихідні елементи повинні бути вимірюваними з метою використання досягнень наук, що мають можливість адаптувати теоретичне знання в практичне [18, с. 11].

Підкреслюючи важливе значення криміналістичної характеристики розбійних нападів, вчинених на водіїв автотранспортних засобів, у розробці техніки, тактики i методики їх розкриття, неправильно було б стверджувати, що криміналістична характеристика злочинів є основою методики розслідування. Вона, будучи важливою та актуальною проблемою курсу криміналістики, 6 складовою частиною, структурним підрозділом, а не методичним принципом, не загальним положенням методики розслідування.
Основоположним у методиці розслідування злочинів є кримінальне, кримінальне процесуальне законодавство та сучасні можливості природничих, технічних і суспільних наук, що визначають рівень розвитку криміналістики. Криміналістичній характеристиці злочинів у розробці методики розслідування належить важлива, але у порівнянні з кримінальною та кримінальною процесуальною характеристиками допоміжна роль.

Одним із важливих положень криміналістики є питання про значущість криміналістичної характеристики злочину та про об'єктивні критерії такої значущості - теоретичний i практичний. Теоретична цінність криміналістичної характеристики злочинів полягає в подальшому розвитку теорії криміналістики, що дозволяє вирішити такі важливі питання, як дослідження та конструювання структури окремої криміналістичної методики, характер взаємозв'язку iї елементів. В узагальненому вигляді найбільш повно і точно практичне значення криміналістичної характеристики полягає в наступному: 1) вона дає змогу слідчому керуватися знаннями про типові риси та особливості розбійних нападів у цілому, а також про їх окремі ознаки, елементи і характер зв'язку між ними, типову слідову картину; 2) вона надає можливість на початковому етапі розслідування, що часто характеризується різким дефіцитом потрібної інформації, використовувати ії дані для побудови загальних та окремих версій, допомагає знайти правильний напрям розслідування; 3) вона відкриває можливість встановлення та використання залежностей і зв'язків між її елементами для пошуку та прогнозування місця знаходження необхідних джерел інформації, а надалі і для виявлення невідомих обставин вчинення розбійних нападів на інкасаторів. Обидва напрями взаємопов'язані та доповнюють один одного. Г. А. Густов переконаний, що криміналістична характеристика злочину - це опис злочину як реального явища, що грунтується на практиці правоохоронних органів та криміналістичних дослідженнях і мета якого полягає в оптимізації процесу розкриття, розслідування злочинів і вирішення завдань правосуддя [19, с. 44]. 
У спеціальній літературі менш виразно представлений інший (операційний) підхід до сутності та призначення криміналістичної характеристики злочинів, відповідно до якого головне іiі призначення полягає в здатності бути моделлю, елементи якої об'єктивно взаємодіють між собою, переносячи в процесі такого взаємозв'язку інформацію про свої ознаки. Найточніше даний аспект криміналістичної характеристики розкрив В. О. Образцов, який визначив ії як сукупність об'єктивних даних про механізм вчинення злочину, засоби відображення, відображені та відображаючі взаємодіючі об'єкти, особливості й джерела сформованої ними фактичної інформації, яка має значення для розкриття певних категорій злочинів шляхом використання обумовлених ними криміналістичних засобів, прийомів і методів, а також розробки наукових рекомендацій щодо оптимального вирішення даного завдання [20, с. 8]. Цей аспект підкреслюе криміналістичний характер вказаного поняття та допомагає відмежувати його від категорій інших юридичних наук, які мають відношення до розслідування злочинів [21, c. 333].

3 криміналістичною характеристикою розбійних нападів пов'язана низка проблем: нерозробленість цілісного поняття даної наукової категорії; прогалини у визначенні структури криміналістичної характеристики розбійних нападів на інкасаторів; відсутність чіткого розмежування між криміналістичною характеристикою і кримінально-правовим та кримінологічним поняттям злочину; неоднозначність поглядів на співвідношення криміналістичної характеристики цієі категорії злочинів і предмета доказування; суперечливість існування криміналістичної характеристики конкретного злочину. Зазначені недоліки концепції криміналістичної характеристики злочинів потребують розробки нової моделі розкриття розбійних нападів на інкасаторів, у криміналістиці шляхом аналізу криміналістичної структури даного злочину.

3 метою покращання якості розслідування кримінальних проваджень розглядуваної категорії варто звернути увагу на наступні положення. По-перше, з'являються нові способи вчинення розбійних нападів, які потребують відповідної розробки їх криміналістичного змісту, що ініціює переоцінку наявних елементів. По-друге, потребує більш грунтовного дослідження поведінка злочинця в посткримінальній фазі, на початковому етапів розслідування. По-третє, актуальна деталізація кожного елемента структури криміналістичної характеристики розбійних нападів, вчинених на інкасаторів, заснована на узагальненні відомостей про елементи вже розкритих злочинів даної категорії.

Отже, криміналістична характеристика розбійних нападів на інкасаторів- ие система криміналістично значущих типових відомостей, що розкривають основні риси предмета, способу злочинного посягання, механізму слідоутворення, обстановки, місия, часу вчинення розбійних нападів, особи злочиния та особи потерпілого в ситуачіях підготовки, вчинення та приховання даної категорї злочинів, шо враховується в методииі розслідування. Дослідження різних аспектів криміналістичної характеристики розбійних нападів на інкасаторів, побудова іiі моделі та прогнозування змін дозволить вирішити цілий комплекс прикладних завдань, пов'язаних із підвищенням ефективності розслідування цих злочинів.

\section{Мітература}

1. Колесниченко А. Н., Коновалова В. Е. Криминалистическая характеристика преступлений: Учеб. пособие. Харьков, Юрид. институт, 1985. 92 с.

2. Драпкин А. Я. Предмет доказывания и криминалистические характеристики преступлений. Криминалистические характеристики в методике расследования преступлений: межвуз. сб. науч. тр. Свердловск, 1978. Вып. 69. С. 16-17.

3. Белкин Р. С. Курс криминалистики. В 3 т. Т. 1: Общая теория криминалистики. М.: Юристь, 1997. 408 с.

4. Гончаренко В. И., Кушнир Г. А., Подпалый В. А. Понятие криминалистической характеристики преступлений. Криминалистика и судебная экспертиза. Киев: Вища школа, 1986. Вып. 33. С. 12-16.

5. Криміналістика: навч. посіб. / за заг. ед. С. В. Пряхіна. Аьвів: АьвДУВС, 2010. $540 \mathrm{c}$. 


\section{Кримінальне право, кримінальний процес та криміналістика}

6. Гаенко В. И. Расследование хищений государственного или общественного имущества, совершённых путём мошенничества: автореф. дис. ... канд. юрид. наук: 12.00.09. Харьков, 1983. 16 с.

7. Журавель В. А. О структуре частной криминалистической методики. Криминалистика и судебная экспертиза. Вып.47. Киев, 1995. С. 63-67.

8. Колесниченко А. Н., Коновалова В. Е. Криминалистическая характеристика преступлений: учеб. пособ. Харьков, Юрид. институт, 1985. 92 с.

9. Салтевський М. В. Криміналістика (у сучасному викладі): підручник. Київ: Кондор, 2008. 588 с.

10. Берназ В. Д. Криміналістична характеристика як наукова категорія. Південноукраїнсъкий правничий часопис. 2006. №1. C. 16-18.

11. Волобуєв А. Ф. Загальні положення криміналістичної методики : лекція. Харків: Ун-т внутр. справ, 1996. 36 с.

12. Яблоков Н. П., Головин А. Ю. Криминалистика: природа и система. М.: Юристь, 2005. 174 с.

13. Щербаковский М. Г. Криминалистика : пособие по подготовке к государственному (выпускному) комплексному экзамену. Харьков : Прометей, 2004. 284 с.

14. Шиканов В. И. О междисциплинарной характеристике отдельных видов преступлений. Криминалистическая характеристика преступлений. Москва, 1984. С. 40-43.

15. Кубрак I. М. Розробки криміналістичних характеристик є одним із напрямків удосконалення методики розслідування злочинів. Актуальні питання розслідування злочинів у сучасних умовах: тактика, методика, інформачійне забезпечення: зб. наук. праць. Київ: УАВС, 1996. С. 13-25.

16. Весельський В. К. Криміналістична характеристика злочинів. Право украйни. 2001. №5. С. 112-114.

17. Сагатовский В. Н. Основы систематизации всеобщих категорий. Томск : Издво Томского университета, 1973. 432 с.

18. Ахмедшин Р. ᄉ. Криминалистическая характеристика личности преступника : автореф. дис...докт. юрид. наук : 12.00.09 «Уголовный процесс, криминалистика и су- дебная экспертиза; оперативно-розыскная деятельность». Томск, 2006. 48 с.

19. Густов Г. А. Понятие и виды криминалистической характеристики преступлений. Криминалистическая характеристика преступлений: сб. науч. тр. Москва, 1984. $106 \mathrm{c}$.

20. Образцов В. А. Проблемы раскрытия преступлений против здоровья населения, связанных с пищевыми отравлениями : автореф. дис...канд. юрид. наук: 12.00.09 «Уголовный процесс, криминалистика и судебная экспертиза; оперативно-розыскная деятельность». Москва, 1976. 26 с.

21. Криминалистика : учеб. / под ред.А. Г. Филиппова, А. Ф. Волынского. Москва : Спарк, 1998. 543 с.

\section{ТЕОРЕТИЧНІ ОСНОВИ ФОРМУВАННЯ КРИМІНАЛІСТИЧНОЇ ХАРАКТЕРИСТИКИ РОЗБІЙНИХ НАПАДІВ НА ІНКАСАТОРІВ}

Складною проблемою сьогодення є питання про розбійні напади на інкасаторів, характерними рисами яких 6 підвищена суспільна небезпека та резонанс, який виникає у зв'язку з відкритим, незаконним, насильницьким нападом на транспортні засоби, поєднаний із посяганням на здоров'я і життя людей, що носить, як правило, груповий організований характер із застосуванням вогнепальної зброї й спрямований на заволодіння матеріальними цінностями у великих розмірах. Під час таких нападів часто гинуть не тільки інкасатори, а й сторонні люди, у зв'язку з тим, що в основному такі напади відбуваються в денний час та в людних місцях, біля великих магазинів та банківських установ.

У статті сформована типова криміналістична характеристика розбійних нападів на інкасаторів. Надано поняття, визначено зміст криміналістичної характеристики розбійних нападів на інкасаторів, розкрито кореляційні зв'язки й залежності між елементами під час конструювання криміналістичної характеристики даного виду злочинів i які в процесі цього виникають труднощі. Зроблена спроба вирішення проблеми виділення рівнів криміналістичної характерис- 
тики злочинів, які не отримали належного наукового обгрунтування і є суперечливими, а тому вимагають уточнення та подальшого розвитку з урахуванням запитів практики i сучасного стану розвитку криміналістики. Підняті питання про значущість криміналістичної характеристики злочину, об’єктивні критерії такої значущості та призначення криміналістичної характеристики розбійних нападів на інкасаторів.

Доведено залежність підвищення якості роботи підрозділів Національної поліції України щодо розслідування розбійних нападів від удосконалення криміналістичної характеристики даного виду злочинів. Обгрунтовано необхідність розробки на основі криміналістичної характеристики системи необхідних практиці дієвих методичних рекомендацій, що розкривають особливості комплексу типових версій і планування в справі, організації розслідування та взаємодії слідчого з оперативними підрозділами й громадськістю, використання спеціальних знань, техніко-криміналістичних засобів і методів, специфіки проведення окремих слідчих (розшукових) дій з метою виявлення обставин, що сприяють вчиненню злочинів, і запобіганню новим розбійним нападам. 3 метою покращання якості розслідування кримінальних справ розглядуваної категорії виділений комплекс прикладних завдань і запропоновано шляхи їх виконання.

Ключові слова: розбій, інкасатори, методика розслідування, криміналістична характеристика.

\section{THEORETICAL BASES OF FORMATION OF THE GRIMINOLOGICAL CHARACTERISTIC OF ROBBERY ATTACKS ON COLLECTORS}

A difficult problem today is the issue of robberies of collectors, characterized by increased public danger and resonance that arises in connection with an open, illegal, violent attack on vehicles, combined with encroachment on the health and lives of people who is, as a rule, a group organized nature with the use of firearms and is aimed at the acquisition of material values on a large scale. Such attacks often kill not only collectors but also outsiders, due to the fact that such attacks occur mainly during the day and in crowded places, near large stores and banks.

The article forms a typical forensic description of robbery attacks on collectors. The concept is given, the content of the forensic characterization of robbery attacks on collectors is defined, the correlations and dependencies between the elements during the construction of the forensic characterization of this type of crime are revealed and what difficulties arise in the process. An attempt is made to solve the problem of identifying the levels of forensic characteristics of crimes that have not received proper scientific justification and are contradictory, and therefore require clarification and further development, taking into account the demands of practice and the current state of forensics. Questions were raised about the significance of the forensic characterization of the crime, the objective criteria for such significance and the purpose of the forensic characterization of robbery attacks on collectors.

The dependence of improving the quality of work of units of the National Police of Ukraine on the investigation of robberies on improving the forensic characteristics of this type of crime has been proved. The necessity of development on the basis of forensic characteristics of the system of effective methodical recommendations necessary for practice, revealing features of a complex of standard versions and planning in case, the organization of investigation and interaction of the investigator with operational divisions and the public, use of special knowledge, forensic means and methods, specifics of carrying out separate investigative (search) actions in order to identify the circumstances that contribute to the commission of crimes and prevent new robberies. In order to improve the quality of the investigation of criminal cases of this category, a set of applied tasks is identified and ways to implement them are proposed.

Key words: robbery, collectors, investigation methods, forensic characteristics. 